\title{
Celtic Christianity
}





\title{
Celtic Christianity
}

Making Myths and Chasing Dreams

\author{
Ian Bradley
}

Edinburgh University Press 
(C) Ian Bradley, 1999

Transferred to Digital Print 2009

Edinburgh University Press

22 George Square, Edinburgh

Typeset in Monotype Ehrhardt by Norman Tilley Graphics, Northampton

Printed and bound in Great Britain by

CPI Antony Rowe, Chippenham and Eastbourne

A CIP record for this book is available from the British Library

ISBN o 7486 I048 o (hardback)

ISBN o 7486 I047 2 (paperback)

The right of Ian Bradley

to be identified as author of this work

has been asserted in accordance with

the Copyright, Designs and Patents Act I988. 